\title{
Modulation of epithelial sodium channel (ENaC) expression in mouse lung infected with Pseudomonas aeruginosa André Dagenais* ${ }^{* 1}$, Diane Gosselin ${ }^{\dagger 2}$, Claudine Guilbault ${ }^{3}$, Danuta Radzioch ${ }^{3}$ and Yves Berthiaume ${ }^{1}$
} \begin{abstract}
and Human Genetics, McGill University, Montreal, Quebec, Canada
Email: André Dagenais* - andre.dagenais.chum@ssss.gouv.qc.ca; Diane Gosselin - dgosselin@fondsftq.com; Claudine Guilbault - claudine.guilbault@mail.mcgill.ca; Danuta Radzioch - danuta.radzioch@muhc.mcgill.ca;

Yves Berthiaume - yves.berthiaume@umontreal.ca

* Corresponding author †Equal contributors
\end{abstract}

Address: ${ }^{1}$ Centre de recherche, Centre hospitalier de l'Université de Montréal/ Hôtel-Dieu, Département de médecine, Université de Montréal Montreal, Quebec, Canada, ${ }^{2}$ Present address: Fonds de solidarité FTQ, Montreal, Quebec, Canada and ${ }^{3}$ Departments of Experimental Medicine

Published: 06 January 2005

Respiratory Research 2005, 6:2 doi:10.1186/1465-9921-6-2
Received: 21 November 2003

Accepted: 06 January 2005

This article is available from: http://respiratory-research.com/content/6/I/2

(c) 2005 Dagenais et al; licensee BioMed Central Ltd.

This is an Open Access article distributed under the terms of the Creative Commons Attribution License (http://creativecommons.org/licenses/by/2.0), which permits unrestricted use, distribution, and reproduction in any medium, provided the original work is properly cited.

\begin{abstract}
Background: The intratracheal instillation of Pseudomonas aeruginosa entrapped in agar beads in the mouse lung leads to chronic lung infection in susceptible mouse strains. As the infection generates a strong inflammatory response with some lung edema, we tested if it could modulate the expression of genes involved in lung liquid clearance, such as the $\alpha, \beta$ and $\gamma$ subunits of the epithelial sodium channel $(\mathrm{ENaC})$ and the catalytic subunit of $\mathrm{Na}^{+}-\mathrm{K}^{+}-\mathrm{ATPase}$.
\end{abstract}

Methods: Pseudomonas aeruginosa entrapped in agar beads were instilled in the lung of resistant $(\mathrm{BalB} / \mathrm{c})$ and susceptible (DBA/2, C57BL/6 and $\mathrm{A} / \mathrm{J})$ mouse strains. The mRNA expression of $\mathrm{ENaC}$ and $\mathrm{Na}^{+}-\mathrm{K}^{+}$-ATPase subunits was tested in the lung by Northern blot following a 3 hours to 14 days infection.

Results: The infection of the different mouse strains evoked regulation of $\alpha$ and $\beta \mathrm{ENaC}$ mRNA. Following Pseudomonas instillation, the expression of $\alpha \mathrm{ENaC}$ mRNA decreased to a median of $43 \%$ on days 3 and 7 after infection and was still decreased to a median of $45 \% \quad 14$ days after infection $(\mathrm{p}<0.05)$. The relative expression of $\beta E N a C$ mRNA was transiently increased to a median of $241 \%, 24 \mathrm{~h}$ post-infection before decreasing to a median of $43 \%$ and $54 \%$ of control on days 3 and 7 post-infection $(p<0.05)$. No significant modulation of $\gamma E N a C$ mRNA was detected although the general pattern of expression of the subunit was similar to $\alpha$ and $\beta$ subunits. No modulation of $\alpha_{1} \mathrm{Na}^{+}-\mathrm{K}^{+}$-ATPase mRNA, the catalytic subunit of the sodium pump, was recorded. The distinctive expression profiles of the three subunits were not different, between the susceptible and resistant mouse strains.

Conclusions: These results show that Pseudomonas infection, by modulating $\mathrm{ENaC}$ subunit expression, could influence edema formation and clearance in infected lungs. 


\section{Background}

The epithelial sodium channel (ENaC) is expressed in epithelial cells of several tissues involved in salt and water reabsorption. The channel is composed of three related subunits $(\alpha, \beta, \gamma)$ that are able to reconstitute a functional channel when expressed in Xenopus laevis oocytes [1,2]. $\mathrm{ENaC}$ is expressed in a wide range of tissues, including the kidney [1,3-5], distal colon [1,3,5], lung [6-8], ear epithelium $[9,10]$, papilla of the tongue [11-13], eyes [14], chondrocytes [15] and differentiating epithelia [16]. $\mathrm{ENaC}$ synthesis and activity are highly regulated by hormones, such as aldosterone, vasopressin and catecholamines, by intracellular $\mathrm{pH}$, feedback inhibition and extracellular proteases $[17,18]$. In the lung, vectorial $\mathrm{Na}^{+}$ transport from the alveoli to the interstitium is the main force that drives water out of the alveoli $[19,20]$. This transport mechanism plays a crucial role late in gestation and at birth when sodium transport is involved in lung liquid clearance [21]. Its importance at birth has been shown unambiguously in $\alpha \mathrm{ENaC}$ gene knockout mice, where the inability to clear lung water rapidly leads to hypoxemia and death [22]. $\mathrm{Na}^{+}$transport is also important in adults for lung liquid clearance $[19,23]$.

Increased $\mathrm{ENaC}$ expression has been detected in the lung and in alveolar epithelial cells in vitro, following stimulation with steroids, $\beta$-agonists, catecholamines, and agents that increase cAMP concentration [24-27]. $\alpha \mathrm{ENaC}$ expression in the lung is modulated at birth when considerable liquid clearance is required $[3,6,27]$. It is also upregulated during hyperoxia $[28,29]$ and downregulated during hypoxia, which could explain high altitude lung edema (HALE) [30,31]. Several lines of evidence suggest that upregulation or downregulation of $\mathrm{ENaC}$ activity in the lung could be associated with lung infection. In type I pseudohypoaldosteronism, a recessive genetic disease leading to a non-functional $\mathrm{ENaC}$, susceptibility to lung infection has been reported [32-34]. Although $\mathrm{ENaC}$ is not the primary defect associated with cystic fibrosis (CF), airway cells from CF patients show a 2-3-fold increase in $\mathrm{Na}^{+}$ transport compared to normal cells $[35,36]$. This sodium hyperabsorption results from the inability of cystic fibrosis transmembrane regulator (CFTR) in CF cells to downregulate ENaC activity $[37,38]$.

Pseudomonas aeruginosa is a bacterium occuring naturally in a wide range of environments such as in soil, fresh and seawater, plants and decomposing organic matter [39]. Although not usually pathogenic, this common bacterium can evoke opportunistic infections in immunodeficient persons, such as patients with severe burns [39]. Pseudomonas can promote nosocomial lung infection after artificial ventilation [40] and is also present in patients with bronchiectasis [39]. Chronic lung infections are the major cause of morbidity and mortality in CF patients
[41] where Pseudomonas aeruginosa is the main source of chronic lung infection in CF patients [42].

Instillation of Pseudomonas aeruginosa in the lung of anaesthetised rabbits has been reported to promote acute pneumonia, resulting in alveolar epithelial injury, loss of epithelial barrier integrity, lung edema, pleural empyema and pleural effusions within $8 \mathrm{~h}$ of infection [43]. A more chronic pneumonia model has been developed in the mouse by the intratracheal instillation of $P$. aeruginosa entrapped in agar beads. In this model, the lungs of susceptible mouse strains develop severe lung infection with a strong inflammatory response and some lung edema $[44,45]$. Pseudomonas by itself has been shown to inhibit active sodium absorption in cultured airway epithelial cells [46]. Here, we studied its impact on the expression of genes involved in the modulation of liquid absorption in alveolar and airway epithelium, namely the three $\mathrm{ENaC}$ subunits and the catalytic subunit of $\mathrm{Na}^{+}-\mathrm{K}^{+}$-ATPase.

Pseudomonas entrapped in agar beads was instilled in the lung of resistant (BalB/c) and susceptible (DBA/2, C57BL/ 6 and $\mathrm{A} / \mathrm{J})$ mouse strains, and the expression of $\alpha, \beta$, $\gamma \mathrm{ENaC}$ and $\alpha_{1} \mathrm{Na}^{+}-\mathrm{K}^{+}$-ATPase mRNA was studied by Northern blotting in lungs infected between 3 hours and 14 days.

\section{Methods}

\section{Infection of mice with $P$. aeruginosa}

Clinical strain 508 of $P$. aeruginosa (provided by Dr. Jacqueline Lagacé, Université de Montréal, Montreal, Canada) was entrapped in agar beads, and $50-\mu$ l suspensions containing $2 \times 10^{5}$ to $1 \times 10^{6} \mathrm{CFU} / \mathrm{ml}$ were instilled intratracheally in male mice of resistant (BALB/c) or susceptible (DBA/2, C57BL/6 and A/J) strains as described previously $[44,45]$.

\section{Macrophage and polymorphonuclear (PMN) counts in bronchoalveolar lavage (BAL)}

BAL were performed as described elsewhere with a few modifications [44]. The infected mice were sacrificed by $\mathrm{CO}_{2}$ inhalation at different time points after $P$. aeruginosa instillation in the lungs. The trachea was cannulated, and the lungs were washed seven times with $1 \mathrm{ml}$ PBS. Total cell counts were conducted in a hemacytometer. Differential cell counts were made by Diff-Quick staining (American Scientific Products) of Cytospin preparations. Number of animals: day $1, \mathrm{n}=6$; day $4, \mathrm{n}=16$; day $6, \mathrm{n}=$ 6; day $14, \mathrm{n}=3$.

\section{Northern blotting}

The lungs from infected mice were harvested between $3 \mathrm{~h}$ to 14 days after infection, homogenized in $5 \mathrm{ml}$ of $4 \mathrm{M}$ guanidine isothiocyanate, and centrifuged on a cesium chloride gradient [44]. Fifteen to $20 \mu \mathrm{g}$ of total RNA 
purified from the lungs were electrophoresed on 1\% agarose-formaldehyde gel and transferred to Nytran membranes (Schleicher \& Schuell, Keene, NH, USA) by overnight blotting with $10 \mathrm{X}$ SSC. Hybridization was performed, as reported previously [3], in Church buffer (0.5 $\mathrm{M}$ Na phosphate, $\mathrm{pH} 7.2,7 \%$ SDS (w/v), 1 mM EDTA, pH 8) [47]. The nylon membranes were hybridized successively with different $c \mathrm{DNA}$ probes. $(\alpha \mathrm{ENaC}, \beta \mathrm{ENaC}$ and $\gamma \mathrm{ENaC}, \quad \alpha_{1} \mathrm{Na}^{+}-\mathrm{K}^{+}$-ATPase, glyceraldehyde-3-phosphate dehydrogenase (GADPH) or $18 \mathrm{~S}$ rRNA). To detect $\alpha \mathrm{ENaC}$ mRNA, the blots were hybridized with 764-bp mouse $\alpha \mathrm{ENaC}$ cDNA (His-445 to stop codon) [3]. The probes for rat $\beta$ and $\gamma \mathrm{ENaC} \mathrm{cDNA}$ were gifts from Dr. B.C. Rossier (Institut de pharmacologie et de toxicologie de l'Université de Lausanne, Lausanne, Switzerland) and coded for the entire cDNA [2]. The $\alpha_{1} \mathrm{Na}^{+}-\mathrm{K}^{+}$-ATPase probe was a gift from Dr. J. Orlowski (Physiology Department, McGill University, Montreal, Quebec, Canada) and consisted of a NarI-StuI 332-bp fragment coding from nucleotide 89 to 421 (from the 5'UTR to Arg-61) of the rat kidney and brain $\alpha$ isoform [48]. For quantitative study, $\alpha \mathrm{ENaC}$ mRNA expression was normalized to murine GADPH with a 455 bp cDNA probe cloned between nucleotide 146 and 601 [44] or with $18 \mathrm{~S}$ rRNA, using a 640-bp cDNA probe between nucleotidet 852 and 1492 of the rat $18 \mathrm{~S}$ rRNA sequence [26]. The blots were exposed to Kodak Xar-film with an intensifying screen, or to a PhosphorImager (Molecular Dynamics, Sunnyvale, CA, USA) for densitometric analysis. Because different strains of mice were investigated in this study (BalB/C, DBA/2, C57BL/6 and A/ $J)$, the expression of the different mRNA was calculated at each time point as the \% of expression relative to an untreated control from the same strain. The data from the different strains were pooled and subjected to statistical analysis.

Between each round of hybridization, the membranes were stripped by treatment with $0.1 \mathrm{X}$ SSC, $1 \%$ SDS and $2.5 \mathrm{mM}$ EDTA at $95^{\circ} \mathrm{C}$. The blots were allowed to cool gradually with agitation for $30 \mathrm{~min}$ at room temperature. The membranes were then rinsed with $5 \mathrm{X}$ SSC and rehybridized. Number of animals: $n=$ between 6 and 8 animals for each time point and each mRNA studied.

\section{Statistics}

For the BAL cell count, the data are presented as means \pm $\mathrm{SE}$ (standard error). For ENaC and $\mathrm{Na}^{+}, \mathrm{K}^{+}$-ATPase mRNA expresion, the comparisons between groups were analyzed by Wilcoxon signed rank non-parametric test using Statsview software (SAS Institute, Inc., Cary, NC, USA). Probability $p$ values $<0.05$ were considered to be significant.

\section{Results \\ Inflammation in mice infected with $P$. aeruginosa}

The inflammation process evoked by Pseudomonas instillation in the lung of $\mathrm{C} 57 \mathrm{BL} / 6$ mice was monitored by studying the number of total cells in BAL at different times after infection. As shown in Figure 1, the inflammation process was more pronounced on days 1 and 4 post-infection. Significant PMN recruitment was noted on day 1 after infection since these cells constituted $90 \%$ of the cell population in BAL at that time (Fig. 1). The proportion of PMN decreased gradually over time. On days 6 and 14, there was a significant reduction of PMN in BAL $(\mathrm{p}<0.05)$ compared to day 1. PMN still constituted $18 \%$ of the cells in BAL on day 14 . The infection also led to modulation in the number of macrophages with a significant increase ( $\mathrm{p}$ $<0.05$ ) on day 4 post-infection (Fig. 1).

\section{Modulation of $\alpha, \beta$ and $\gamma \mathrm{ENaC}$ expression following lung infection with $P$. aeruginosa}

Pseudomonas embedded in agar beads was administered intratracheally in resistant (BALB/c) and susceptible strains of mice (DBA/2, C57BL/6, A/J) as described previously $[44,49] . \alpha, \beta$ and $\gamma \mathrm{ENaC}$ expression in infected lungs was measured by Northern blot hybridization (Fig. 2). Expression of the three subunits was highly modulated in time after lung infection, but showed a similar pattern between the four mouse strains tested. The BALB/c strain that is resistant to Pseudomonas infection [45], as well as the DBA/2, C57BL/6 and A/J susceptible strains, showed increased $\alpha, \beta$ and $\gamma \mathrm{ENaC}$ expression at $24 \mathrm{~h}$, followed by a decrease on day 3 post-infection. The GADPH standard gene did not manifest any modulation of its expression. Densitometric quantitative analyses of the Northern blots were performed for the four mouse strains. The relative expression at each time point was determined relative to uninfected animals of the same strain and the data from the 4 strains were pooled for analysis (Fig. 3). $\alpha \mathrm{ENaC}$ mRNA expression presented a significant decline to a median of $43 \%$ on days 3 and 7 post-infection, and was still decreased to a median of $45 \%$ on day 14 post-infection compared to uninfected controls ( $\mathrm{p}<0.05$, Fig. 3 ). $\beta \mathrm{ENaC}$ mRNA expression was increased to a median of $241 \%$ of uninfected control values, 24 h post-infection ( $p$ $<0.05)$, and was followed by a decrease to medians of $42 \%$ and $54 \%$ on day 3 and 7 post-infection ( $<<0.05)$ (Fig. 3). Although the expression of $\gamma$ ENaC mRNA showed an expression pattern very similar to the $\alpha$ and $\beta E N a C$ subunits, with an increased expression at $24 \mathrm{~h}$ (median of $171 \%$ ) followed by a decreased expression on day 3 (median of 53\%) and 7 (median of 66\%) of infection, these changes failed however to reach significance (Fig. 3). No modulation of $\alpha, \beta$ or $\gamma \mathrm{ENaC}$ mRNA was detected when the lungs were instilled with agarose beads only (data not shown). We also investigated the 
Total cells in BAL

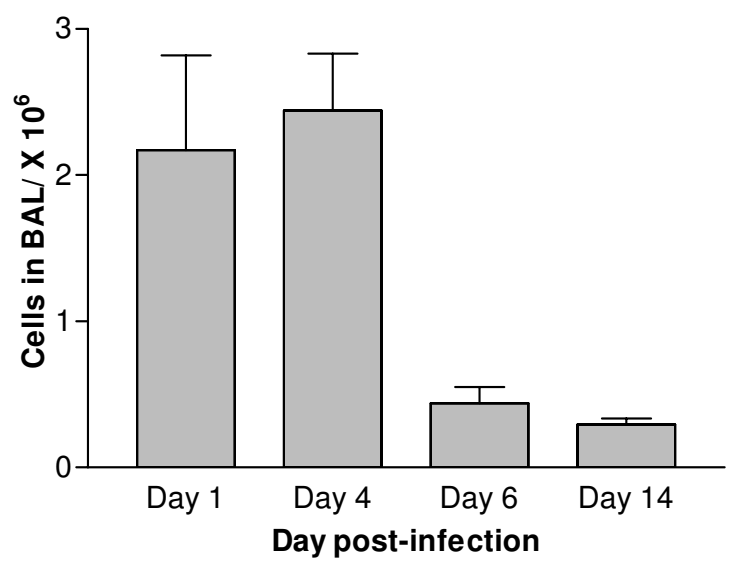

PMN in BAL

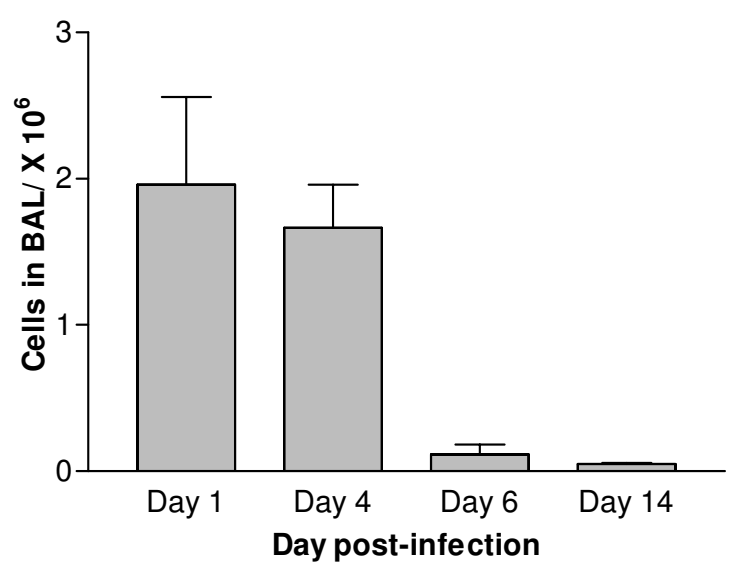

\% Macrophages and PMN in BAL

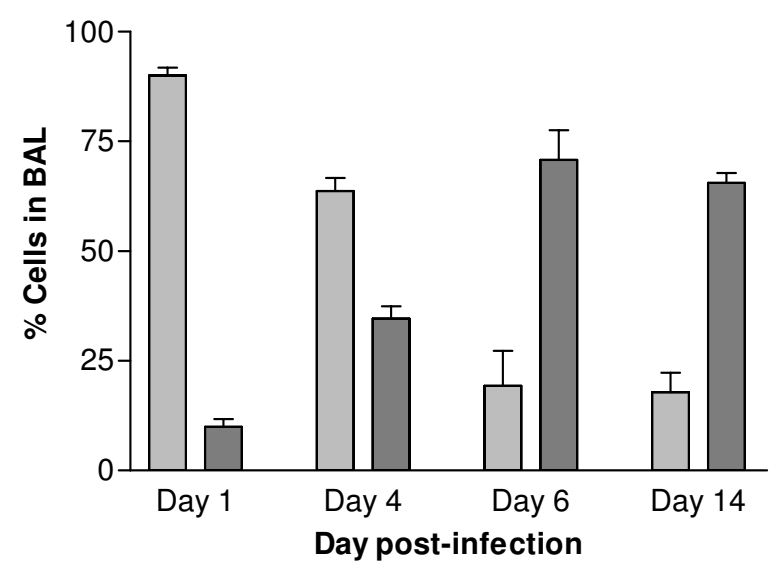

Macrophages in BAL

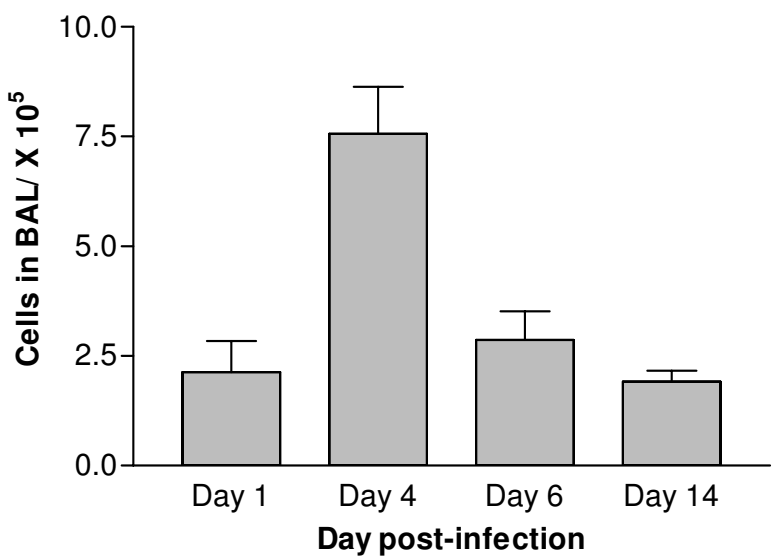

Figure I

Differential cell counting in C57BL/6 mice infected with I-2 × $10^{5}$ Pseudomonas aeruginosa embedded in agar beads. Pseudomonas infection leads to strong inflammation with recruitment of PMN and macrophages in bronchoalveolar lavage on days I and 4 post-infection. Day I, $n=6$; day $4, n=16$; day $6, n=6$; day I4, $n=3$. Differential cell counting: PMN in light grey, macrophages in dark grey.

expression of $\alpha_{1} \mathrm{Na}^{+}-\mathrm{K}^{+}$-ATPase mRNA coding for the catalytic domain of the sodium pump, but could not find any significant change during infection (Fig. 3).

\section{Discussion}

The instillation of Pseudomonas enmeshed in agarose beads in the lung is a good model to study lung inflammation $[44,45]$ and lung injury [43] secondary to an infection. For this study, $P$. aeruginosa enmeshed in agarose beads was instilled into the mouse lung because the model allows the development of chronic lung infection in susceptible mouse strains $[44,45]$. The infection leads to cellular infiltration and alveolar edema that stand on day 3 post-infection and that can be still demonstrated on day 14 post-infection in Pseudomonas-susceptible mouse strains [45]. Because the lung inflammation associated with Pseudomonas infection is accompanied by lung injury [43], and because we have shown recently that ENaC expression can be modulated under conditions that promote lung injury [50], we tested here if Pseudomonas was affecting the mRNA expression level of the three ENaC subunits as well as the catalytic subunit of the $\mathrm{Na}^{+}$pump 


\section{C57BL/6 BALB/C $\quad$ DBA/2 $\quad A / J$}

Time post-infection

0 3h $6 h$ 1d 3d 7d 0 3h 6h 1d 3d 7d

0 3h $6 h$ 1d 3d 7d

$03 h 6 h 1 d 3 d 7 d$

$\alpha \mathrm{ENaC}$
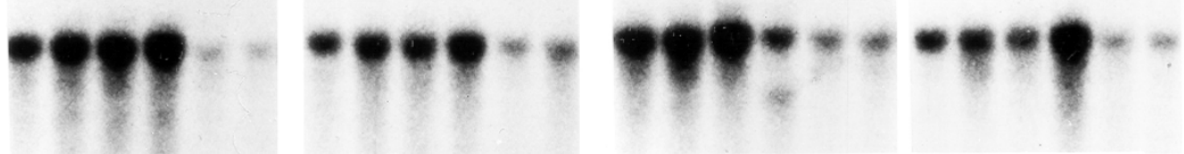

$\beta E N a C$
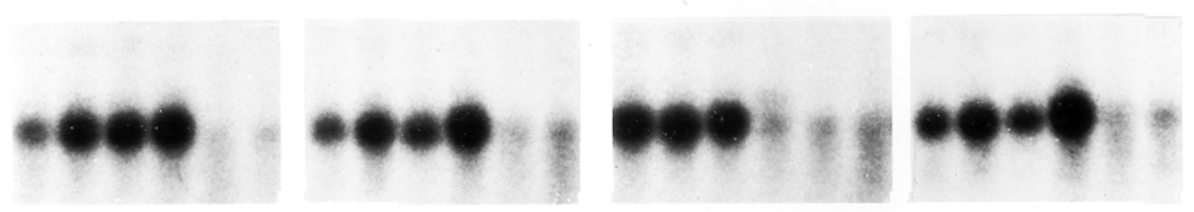

$\gamma \mathrm{ENaC}$
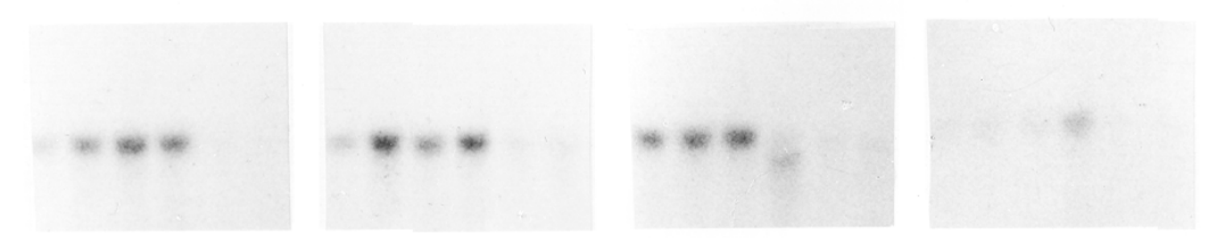

\section{GADPH}
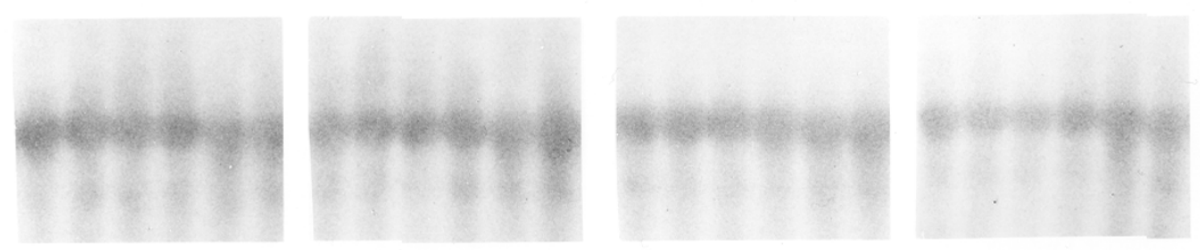

\section{Figure 2}

Expression of $\alpha, \beta$ and $\gamma E N a C$ mRNA in the lung following infection with Pseudomonas aeruginosa. Representative Northern blot of $\alpha, \beta$ and $\gamma \mathrm{ENaC}$ mRNA expression following infection with Pseudomonas in resistant (BalB/c) and susceptible (DBA/2, C57BL/6 and A/J) strains of mice. There is a characteristic modulation of the three ENaC subunits that is not different between strains.

since these elements are involved in lung liquid balance across the alveolar epithelium $[19,23]$. The results reported here indicate that Pseudomonas infection modulated the expression of the three ENaC mRNA with a characteristic pattern. There was no significant difference, however, in the expression profile of ENaC mRNA between the Pseudomonas-resistant (Balb/C) and -susceptible (DBA/2, C57BL/6, A/J) mouse strains. Modulation of $\mathrm{ENaC}$ expression is therefore most likely not a genetic marker linked to the susceptibility of mouse strains to establishment of a chronic infection with Pseudomonas.
Pseudomonas infection affected ENaC mRNA with a pattern consisting of increased expression at $24 \mathrm{~h}$, followed by a marked decrease on day 3 post-infection. The change in $\mathrm{ENaC}$ mRNA was related to bacterial infection, since agarose beads alone failed to evoke any modulation of these RNA. The three ENaC subunits were modulated with a similar profile, with some noticeable differences, however. Although $\alpha \mathrm{ENaC}$ mRNA expression tends to increase by day 1 , the most noticeable feature brought by Pseudomonas infection to $\alpha \mathrm{ENaC}$ mRNA was the significant decreases after 3 days, 7 days and 14 days post-infection. 


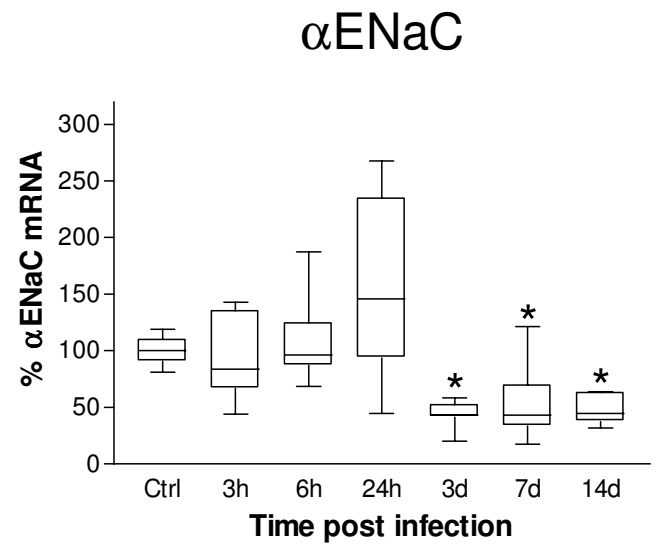

$\gamma \mathrm{ENaC}$

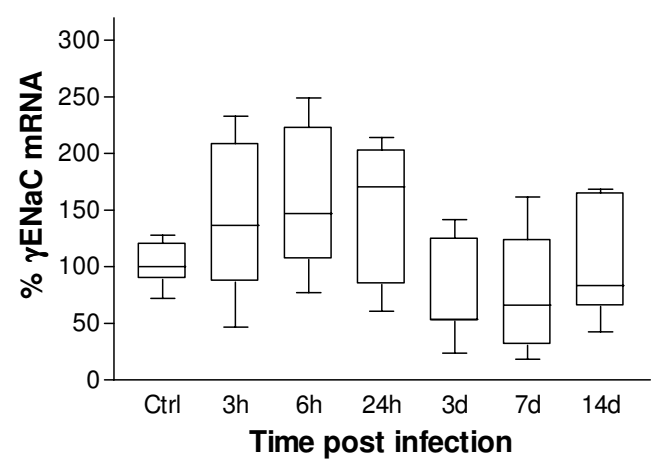

$\beta \mathrm{ENaC}$

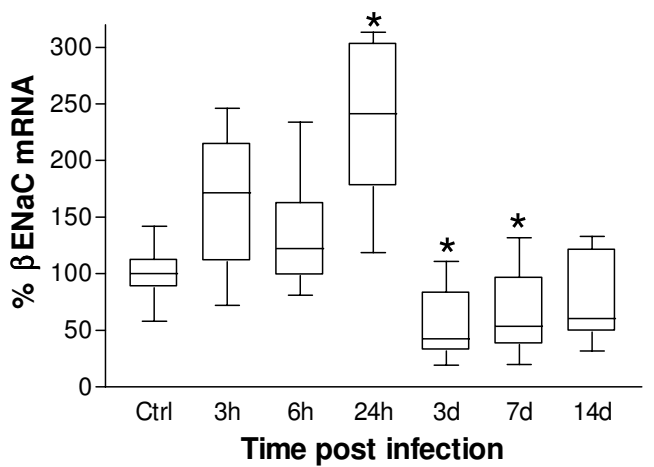

$\alpha \mathrm{Na}, \mathrm{K}-\mathrm{ATP}$ ase

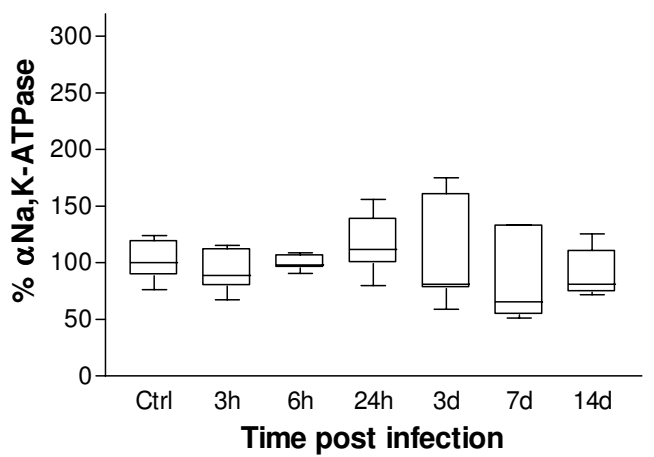

Figure 3

Densitometric analysis of the modulation of $\alpha \mathrm{ENaC}, \beta \mathrm{ENaC}, \gamma \mathrm{ENaC}$ and $\alpha_{1} \mathrm{Na}^{+}-\mathrm{K}^{+}$-ATPase mRNA following Pseudomonas infection. The modulation of $\alpha \mathrm{ENaC}, \beta \mathrm{ENaC}, \gamma \mathrm{ENaC}$ and $\alpha_{1} \mathrm{Na}^{+}-\mathrm{K}^{+}-\mathrm{ATPase} m \mathrm{mNA}$ by Northern blots hybridization was subjected to a densitometric analysis. Because different strains of mice were investigated in this study (BalB/ c, DBA/2, C57BL/6 and A/J), the expression of the different mRNA was calculated at each time point as the \% of expression relative to an untreated control coming from the same strain. The $\alpha$ and $\beta E N a C$ mRNA were modulated at some time point by Pseudomonas infection compared to uninfected animals. There was no modulation for $\gamma \mathrm{ENaC}$ or $\alpha_{1} \mathrm{Na}^{+}-\mathrm{K}^{+}-\mathrm{ATPase}$ mRNA. $\alpha \mathrm{ENaC}$ mRNA was downregulated compared to uninfected controls on days 3,7 and I 4 post-infection $(*, \mathrm{p}<0.05)$. $\beta \mathrm{ENaC}$ mRNA was elevated at $24 \mathrm{~h}$ post-infection $(*, p<0.05)$ compared to uninfected controls and was downregulated thereafter on day 3 and 7 post-infection (*, $p<0.05$ ). Number of animals: $n=$ between 6 and 8 animals for each time point and each mRNA studied.

To the best of our knowledge, this is the first report demonstrating that bacterial infection in vivo can lead to modulation of ENaC mRNA expression. Recently, $\alpha \mathrm{ENaC}$ mRNA expression was found to be downregulated in the mouse lung after 7 and 14 days of adenoviral infection [51]. Furthermore, there is some evidence that $\alpha \mathrm{ENaC}$ expression is also decreased in other models of lung injury. Folkesson et al. [52] reported a decline in ENaC expression following subacute lung injury, 10 days after intratracheal administration of bleomycin. More recently, we recorded a decrease in $\mathrm{ENaC}$ expression after ischemiareperfusion lung injury [50]. All these results, and the 
results reported in the present report, suggest that the modulation of ENaC expression associated with lung infection could be a widespread mechanism, not specific to a given pathogen or injury process, but a general response of the lung to inflammation and injury.

The $\beta \mathrm{ENaC}$ subunit was also modulated by Pseudomonas infection. There was a significant increase in the mRNA expression on day 1 post-infection, followed, as for $\alpha \mathrm{ENaC}$, by a decreased expression on day 3 and day 7 post-infection. Different stoichiometries have been proposed for $\mathrm{ENaC}$. One model suggests a $2 \alpha, \beta, \gamma$ ratio $[53,54]$ whereas others postulate an octomeric [55] or nonameric structure $[55,56]$. Although the expression of the $\alpha$ subunit alone is sufficient to allow ENaC activity [1], the three subunits are needed to get a fully functional channel [2]. The expression of the three subunits in Xenopus laevis oocytes increases amiloride-sensitive $\mathrm{Na}^{+}$current by $100 \%$ compared to $\alpha \mathrm{ENaC}$ alone [2]. The $\alpha, \beta$ and $\alpha, \gamma$ channels are 20 times less effective in driving amiloridesensitive current than the native channels and show differences in their biophysical properties $[57,58]$. Gene inactivation or over-expression of the different $\mathrm{ENaC}$ subunits has revealed important differences in the role each subunit plays in lung liquid management. $\alpha \mathrm{ENaC}$ knockout mice develop respiratory distress and die within $40 \mathrm{~h}$ from birth because of their inability to clear lung liquid [22]. Lung liquid clearance at birth is also slower in $\gamma \mathrm{ENaC}$ knockout mice [59], but is not affected in $\beta \mathrm{ENaC}$ knockouts [60]. Increased transgenic expression of $\beta E N a C$ targeted in the airway epithelia, but not $\alpha$ or $\gamma$ subunits, showed an increase $\mathrm{Na}^{+}$transport across the airway epithelium and a reduced height of the airway surface liquid [61]. For all these reasons, it is difficult to predict how the modulation of ENaC mRNA expression and its effect on the ratio of the three subunits, would have an impact on ENaC activity. In addition, ENaC mRNA content also does not necessarily reflect the amount of active channel at the membrane. One thing seems clear however, because of its prominence in the lung, the diminution of $\alpha \mathrm{ENaC}$ expression that we detected in the lung following Pseudomonas infection, could certainly influence amiloride-sensitive current and lung liquid clearance as in $\alpha \mathrm{ENaC} \mathrm{KO}$ mice rescued by transgenic expression of $\alpha \mathrm{ENaC}$ that has a lower expression of $\mathrm{ENaC}$ in the lung $[62,63]$. In such model, there is a reduced $\mathrm{ENaC}$ current in tracheal cells [63], and a much slower lung liquid clearance following thiourea or hyperoxia-induced lung edema [64].

The general biphasic modulation of ENaC mRNA expression with an increase at $24 \mathrm{~h}$ followed by a decrease thereafter is an interesting finding that could explain some contradictory reports concerning ENaC expression in lung following Pseudomonas infection. Acute bacterial pneumonia in rats has been shown to increase alveolar epithelial fluid clearance $[65,66]$ when in late pneumonia, there is a decrease in the lung liquid clearance ability of the lung [66]. These contradictory results could be well explained by the modulation of ENaC expression reported here. The long term ENaC downregulation by Pseudomonas infection could be of potential clinical significance to understand the slow improvement in some ARDS patients.

In contrast to $\alpha$ and $\beta \mathrm{ENaC}, \alpha_{1} \mathrm{Na}^{+}-\mathrm{K}^{+}$-ATPase mRNA was unaffected in the course of lung infection. This is similar to what has been reported during adenovirus lung infection [51] where $\alpha E N a C$, aquaporin 1 (AQP1) and AQP5 mRNA show decreased expression, but not $\alpha_{1} \mathrm{Na}^{+-} \mathrm{K}^{+}-$ ATPase. In ischemia reperfusion injury, there was also no modulation of $\alpha_{1} \mathrm{Na}^{+}-\mathrm{K}^{+}$-ATPase expression despite significant ENaC downregulation [50]. These results, as well as the data reported here, suggest that the inflammatory process seems to selectively affect, and not in a non-specific way, some elements of lung liquid clearance. It would be difficult at this time to speculate on the reasons for this modulation. $\mathrm{Na}^{+}-\mathrm{K}^{+}$-ATPase is an important element in lung liquid clearance, however, by being one of the key generator of membrane potential, the enzyme also affects other channels and ion transport process. It is possible that by modulating ENaC expression and not $\alpha_{1} \mathrm{Na}^{+-} \mathrm{K}^{+}-$ ATPase, Pseudomonas infection alters the $\mathrm{Na}^{+}$transport system but does not change other important cell functions meditated by $\mathrm{Na}^{+}-\mathrm{K}^{+}$-ATPase. Furthermore, despite a similar mRNA expression level, there could be a fall in protein content or activity of the sodium pump. Additional experiments are necessary to answer this question.

Several studies report that in lung epithelial cells, viral infection [67,68], mycoplasma [69], bacterial infection $[70,71]$, and inflammatory cytokines such as tumor necrosis factor- $\alpha$ (TNF- $\alpha)[70,72]$, interleudin-1 $\beta$ (IL-1 $\beta$ ) [73], or TGF- $\beta$ [74] decrease the expression of water channels, such as AQP1 and AQP5 and reduce the short circuit current generated by cells. Adenoviral lung infection in mice results in pulmonary inflammation and lung edema with lowered expression of AQP1, AQP5 and $\alpha$ ENaC [51]. All these data, including the results presented here, suggest that lung inflammation, by decreasing the expression of $\alpha \mathrm{ENaC}$ and water channels, could hamper the liquid clearance ability of the lungs and favour edema formation.

\section{Conclusions}

We have shown in this report that Pseudomonas infection modulates ENaC mRNA expression. This modulation is independent of mouse strain susceptibility to establishment of chronic infection with Pseudomonas. Although there is an elevation of ENaC expression after $24 \mathrm{~h}$, the most important feature is probably the long-lasting decrease of $\alpha \mathrm{ENaC}$ transcripts on days 3 and 7 post-infec- 
tion. The lung inflammation induced by Pseudomonas infection therefore seems to favour a reduction in the expression of an essential element involved in lung liquid clearance as well as the regulation of airway surface liquid volume.

\section{Authors' contributions}

$\mathrm{AD}$ performed the hybridization, the statistical analysis of the blots and wrote the manuscript. DG performed the Pseudomonas instillation, RNA extraction and Northern blotting of RNA sample. The BAL recovery as well as PMN and macrophage counting was performed by CG. YB and DR designed and co-ordinated the study. All authors read and approved the final manuscript.

\section{Acknowledgements}

Dr Yves Berthiaume and Dr. Danuta Radzioch are Chercheur-Nationaux from Fonds de la recherche en santé du Québec. This work was supported in part by the Canadian Cystic Fibrosis Foundation and the Canadian Institutes of Health Research. The authors acknowledge the editorial work on this manuscript by Ovid Da Silva, éditeur/rédacteur of the Research Support Office of the CHUM Research Center.

\section{References}

I. Canessa CM, Horisberger J-D, Rossier BC: Epithelial sodium channel related to proteins involved in neurodegeneration. Nature 1993, 36 I:467-470.

2. Canessa CM, Schild L, Buell G, Thorens B, Gautschi I, Horisberger J$\mathrm{D}$, et al: Amiloride-sensitive epithelial $\mathrm{Na}^{+}$channel is made of three homologous subunits. Nature 1994, 367:463-467.

3. Dagenais A, Kothary R, Berthiaume $Y$ : The $\alpha$ subunit of the epithelial sodium channel in the mouse: developmental regulation of its expression. Pediatr Res 1997, 42:327-334.

4. Dijkink L, Hartog A, Deen PM, Van Os CH, Bindels RJ: Timedependent regulation by aldosterone of the amiloride-sensitive $\mathrm{Na}+$ channel in rabbit kidney. Pflugers Arch 1999, 438:354-360.

5. Renard S, Voilley N, Bassilana F, Lazdunski M, Barbry P: Localization and regulation by steroids of the alpha, beta and gamma subunits of the amiloride-sensitive $\mathrm{Na}^{+}$channel in colon, lung and kidney. Pflügers Arch 1995, 430:299-307.

6. Voilley N, Lingueglia E, Champigny G, Mattéi M-G, Waldmann R, Lazdunski $M$, et al:: The lung amiloride-sensitive $\mathbf{N a}^{+}$channel: Biophysical properties, pharmacology, ontogenesis, and molecular cloning. Proc Natl Acad Sci USA 1994, 91 :247-25I.

7. O'Brodovich H, Canessa C, Ueda J, Rafll B, Rossier BC, Edelson J: Expression of the epithelial $\mathrm{Na}^{+}$channel in the developing rat lung. Am J Physiol 1993, 265:C49I-C496.

8. Champigny G, Voilley N, Lingueglia E, Friend V, Barbry P, Lazdunski $M$ : Regulation of expression of the lung amiloride-sensitive $\mathrm{Na}^{+}$channel by steroid hormones. EMBO J 1994, 13:2177-2 I8I.

9. Herman P, Tan C-T, Van den Abbeele T, Escoubet B, Friedlander G, Tran Ba Huy $P$ : Glucocorticosteroids increase sodium transport in middle ear epithelium. Am J Physiol 1997, 272:C184-C190.

10. Portier F, Van den Abbeele T, Lecain E, Sauvaget E, Escoubet B, Tran Ba Huy $\mathrm{P}$, et al:: Oxygen modulates $\mathrm{Na}^{+}$absorption in middle ear epithelium. Am J Physiol 1999, 276:C3 I2-C317.

II. Li XJ, Xu RH, Guggino WB, Snyder SH: Alternatively spliced forms of the alpha subunit of the epithelial sodium channel: distinct sites for amiloride binding and channel pore. Mol Pharmacol 1995, 47: I|33-I|40.

12. Kretz $O$, Barbry $P$, Bock R, Lindemann B: Differential expression of RNA and protein of the three pore-forming subunits of the amiloride-sensitive epithelial sodium channel in taste buds of the rat. J Histochem Cytochem 1999, 47:51-64.
13. Lin W, Finger TE, Rossier BC, Kinnamon SC: Epithelial $\mathbf{N a}^{+}$channel subunits in rat taste cells: Localization and regulation by aldosterone. J Comp Neurol 1999, 405:406-420.

14. Mirshahi M, Nicolas C, Mirshahi S, Golestaneh N, d'Hermies F, Agarwal MK: Immunochemical analysis of the sodium channel in rodent and human eye. Exp Eye Res 1999, 69:21-32.

I5. Trujillo E, Alvarez dIR, Mobasheri A, Gonzalez T, Canessa CM, Martin-Vasallo P: Sodium transport systems in human chondrocytes. II. Expression of ENaC, $\mathrm{Na}+/ \mathrm{K}+/ 2 \mathrm{Cl}$ - cotransporter and $\mathrm{Na}+/ \mathrm{H}+$ exchangers in healthy and arthritic chondrocytes. Histol Histopathol 1999, I4:1023-1031.

16. Brouard M, Casado M, Djelidi S, Barrandon Y, Farman N: Epithelial sodium channel in human epidermal keratinocytes: expression of its subunits and relation to sodium transport and differentiation. J Cell Sci 1999, I I 2:3343-3352.

17. Garty H, Palmer LG: Epithelial sodium channels: function, structure, and regulation. Physiol Rev 1997, 77:359-396.

18. Fyfe GK, Quinn A, Canessa CM: Structure and function of the Mec-ENaC family of ion channels. Semin Nephrol 1998, I 8: $|38-15|$.

19. Matthay MA, Folkesson HG, Verkman AS: Salt and water transport across alveolar and distal airway epithelia in the adult lung. Am J Physiol 1996, 270:L487-L503.

20. Berthiaume $Y$ : Mechanisms of edema clearance. In In Pulmonary edema Edited by: Weir EK, Reeves JT. Armonk: Futura Publishing Company, inc; 1998:77-94

21. Folkesson HG, Norlin A, Baines DL: Salt and water transport across the alveolar epithelium in the developing lung: correlations between function and recent molecular biology advances (review). Int J Mol Med I998, 2:5 I5-53 I.

22. Hummler E, Barker P, Gatzy J, Beermann F, Verdumo C, Schmidt A, et al.: Early death due to defective neonatal lung liquid clearance in alphaENaC-deficient mice. Nature Genet 1996 , I 2:325-328.

23. Berthiaume $Y$, Folkesson HG, Matthay MA: Lung edema clearance: $\mathbf{2 0}$ years of progress: invited review: alveolar edema fluid clearance in the injured lung. I Appl Physiol 2002, 93:2207-22I3.

24. Dumasius V, Sznajder JI, Azzam ZS, Boja J, Mutlu GM, Maron MB, et al.: Beta(2)-adrenergic receptor overexpression increases alveolar fluid clearance and responsiveness to endogenous catecholamines in rats. Circ Res 2001, 89:907-914.

25. Minakata Y, Suzuki S, Grygorczyk C, Dagenais A, Berthiaume Y: Impact of the beta-adrenergic agonist terbutaline on $\mathrm{Na}^{+}$ channel and $\mathrm{Na}^{+}-\mathrm{K}^{+}$-ATPase expression in alveolar type II cells. Am J Physiol 1998, 275:L4I4-L422.

26. Dagenais A, Denis C, Vives MF, Girouard S, Masse C, Nguyen T, et al.: Modulation of alpha-ENaC and alpha(I)-Na+-K+-ATPase by CAMP and dexamethasone in alveolar epithelial cells. Am J Physiol Lung Cell Mol Physiol 200I, 28I :L217-L230.

27. Finley N, Norlin A, Baines DL, Folkesson HG: Alveolar epithelial fluid clearance is mediated by endogenous catecholamines at birth in guinea pigs. J Clin Invest 1998, I0 I:972-981.

28. Pitkänen O, Tanswell AK, Downey G, O'Brodovich H: Increased $\mathrm{PO}_{2}$ alters the bioelectric properties of fetal distal lung epithelium. Am J Physiol 1996, 270:L I060-LI066.

29. Yue G, Russel WJ, Benos DJ, Jackson RM, Olman MA, Matalon S: Increased expression and activity of sodium channels in alveolar type II cells of hyperoxic rats. Proc Natl Acad Sci U S A 1995, 92:8418-8422.

30. Planès $C$, Escoubet $B$, Blot-Chabaud $M$, Friedlander G, Farman $N$, Clerici C: Hypoxia downregulates expression and activity of epithelial sodium channels in rat alveolar epithelial cells. Am J Respir Cell Mol Biol I 997, I 7:508-5I8.

31. Wodopia R, Ko HS, Billian J, Wiesner R, Bartsch P, Mairbaurl H: Hypoxia decreases proteins involved in epithelial electrolyte transport in A549 cells and rat lung. Am J Physiol Lung Cell Mol Physiol 2000, 279:LI I I0-LI I I9.

32. Hanukoglu A, Bistritzer T, Rakover Y, Mandelberg A: Pseudohypoaldosteronism with increased sweat and saliva electrolyte values and frequent lower respiratory tract infections $\mathrm{mim}$ icking cystic fibrosis. J Pediatr 1994, I 25:752-755.

33. Marthinsen L, Kornfalt R, Aili M, Andersson D, Westgren U, Schaedel $C$ : Recurrent Pseudomonas bronchopneumonia and other symptoms as in cystic fibrosis in a child with type I pseudohypoaldosteronism. Acta Paediatr 1998, 87:472-474. 
34. Schaedel C, Marthinsen L, Kristoffersson AC, Kornfalt R, Nilsson KO, Orlenius $B$, et al.: Lung symptoms in pseudohypoaldosteronism type I are associated with deficiency of the $\alpha$-subunit of the epithelial sodium channel. I Pediatr 1999, I 35:739-745.

35. Boucher RC, Cotton CU, Gatzy JT, Knowles MR, Yankaskas JR: Evidence for reduced $\mathrm{Cl}$ - and increased $\mathrm{Na}+$ permeability in cystic fibrosis human primary cell cultures. J Physiol (Lond) 1988, 405:77-103.

36. Boucher RC, Stutts MJ, Knowles MR, Cantley L, Gatzy JT: Na+ transport in cystic fibrosis respiratory epithelia. Abnormal basal rate and response to adenylate cyclase activation. J Clin Invest 1986, 78: | 245-1252.

37. Stutts MJ, Canessa CM, Olsen JC, Hamrick M, Cohn JA, Rossier BC, et al:: CFTR as a CAMP-dependent regulator of sodium channels. Science 1995, 269:847-850.

38. Stutts MJ, Rossier BC, Boucher RC: Cystic fibrosis transmembrane regulator inverts protein kinase $A$-mediated regulation of epithelial sodium channel single channel kinetics. J Biol Chem 1997, 272:|4037-|4040.

39. Wilson R, Dowling RB: Lung infections. 3. Pseudomonas aeruginosa and other related species. Thorax 1998, 53:213-219.

40. Craven DE, Steger KA: Ventilator-associated bacterial pneumonia: challenges in diagnosis, treatment, and prevention. New Horiz 1998, 6:S30-S45.

41. Bye MR, Ewig JM, Quittel LM: Cystic Fibrosis. Lung 1994, I 72:25I-270.

42. Collins FS: Cystic fibrosis: molecular biology and therapeutic implications. Science 1992, 256:774-779.

43. Wiener-Kronish JP, Sakuma T, Kudoh I, Pittet JF, Frank D, Dobbs L, et al:: Alveolar epithelial injury and pleural empyema in acute P. aeruginosa pneumonia in anesthetized rabbits. J Appl Physiol 1993, 75:1661-1669.

44. Gosselin D, DeSanctis J, Boulé M, Skamene E, Matouk C, Radzioch D: Role of tumor necrosis factor alpha in innate resistance to mouse pulmonary infection with Pseudomonas aeruginosa. Infect Immun 1995, 63:3272-3278.

45. Morissette C, Skamene E, Gervais F: Endobronchial inflammation following Pseudomonas aeruginosa infection in resistant and susceptible strains of mice. Infect Immun 1995, 63:1718-1724.

46. Evans DJ, Matsumoto PS, Widdicombe JH, Li-Yun C, Maminishkis aA, Miller SS: Pseudomonas aeruginosa induces changes in fluid transport across airway surface epithelia. Am J Physiol 1998, 275:CI284-CI290.

47. Church GM, Gilbert W: Genomic sequencing. Proc Natl Acad Sci USA 1984, 8I:1991-1995.

48. Shull GE, Greeb J, Lingrel JB: Molecular cloning of three distinct forms of the $\mathrm{Na}^{+}$, $\mathrm{K}^{+}$-ATPase alpha-subunit from rat brain. Biochemistry 1986, 25:8|25-8132.

49. Gosselin D, Stevenson MM, Cowley EA, Griesenbach U, Eidelman $\mathrm{DH}$, Boulé $\mathrm{M}$, et al.: Impaired ability of Cftr knockout mice to control lung infection with Pseudomonas aeruginosa. Am J Respir Crit Care Med 1998, I 57:I253-1262.

50. Sugita M, Ferraro P, Dagenais A, Clermont ME, Barbry P, Michel RP, et al:: Alveolar liquid clearance and sodium channel expression are decreased in transplanted canine lungs. Am J Respir Crit Care Med 2003, 167:1440-1450.

5I. Towne JE, Harrod KS, Krane CM, Menon AG: Decreased expression of aquaporin (AQP)I and AQP5 in mouse lung after acute viral infection. Am J Respir Cell Mol Biol 2000, 22:34-44.

52. Folkesson HG, Nitenberg G, Oliver BL, Jayr C, Albertine KH, Matthay MA: Upregulation of alveolar epithelial fluid transport after subacute lung injury in rats from bleomycin. Am J physiol 1998, 275:L478-L490.

53. Firsov D, Gautschi I, Merillat A-M, Rossier BC, Schild L: The heterotetrameric architecture of the epithelial sodium channel (ENaC). EMBO J 1998, I 7:344-352.

54. Kosari F, sheng S, Li J, Mak D-OD, Foskett JK, Kleyman TR: Subunit stoichiometry of the epithelial sodium channel. J Biol Chem 1998, 273: I3469-13474.

55. Eskandari S, Snyder PM, Kreman M, Zampighi GA, Welsh MJ, Wright EM: Number of subunits comprising the epithelial sodium channel. J Biol Chem 1999, 274:2728|-27286.

56. Snyder PM, Cheng C, Prince LS, Rogers JC, Welsh MJ: Electrophysiological and biochemical evidence that DEG/ENaC cation channels are composed of nine subunits. J Biol Chem 1998, 273:68|-684.
57. McNicholas CM, Canessa CM: Diversity of channels generated by different combinations of epithelial sodium channel subunits. J Gen Physiol 1997, 109:681-692.

58. Fyfe GK, Canessa CM: Subunit composition determines the single channel kinetics of the epithelial sodium channel. J Gen Physiol 1998, I I 2:423-432.

59. Barker PM, Nguyen MS, Gatzy JT, Grubb B, Norman H, Hummler E, et al: Role of gamma-ENaC subunit in lung liquid clearance and electrolyte balance in newborn mice. Insights into perinatal adaptation and pseudohypoaldosteronism. J Clin Invest 1998, 102:1634-1640.

60. McDonald FJ, Yang B, Hrstka RF, Drummond HA, Tarr DE, McCray PB Jr, et al.: Disruption of the beta subunit of the epithelial $\mathrm{Na}^{+}$ channel in mice: Hyperkalemina and neonatal death associated with pseudohypoaldosteronism phenotype. Proc Natl Acad Sci USA 1999, 96:|727-|731.

6I. Mall M, Grubb BR, Harkema JR, O'Neal WK, Boucher RC: Increased airway epithelial $\mathbf{N a ( + )}$ absorption produces cystic fibrosislike lung disease in mice. Nat Med 2004, 10:487-493.

62. Hummler E, Barker P, Talbot C, Wang Q, Verdumo C, Grubb B, et al: A mouse model for the renal salt-wasting syndrome pseudohypoaldosteronism. Proc Natl Acad Sci USA 1997, 94:11710-11715.

63. Olivier R, Scherrer U, Horisberger JD, Rossier BC, Hummler E: Selected contribution: limiting $\mathrm{Na}(+)$ transport rate in airway epithelia from alpha-ENaC transgenic mice: a model for pulmonary edema. J Appl Physiol 2002, 93:I88I-I887.

64. Egli M, Duplain H, Lepori M, Cook S, Nicod P, Hummler E, et al: Defective Respiratory Amiloride Sensitive Sodium Transport Predisposes To Pulmonary Oedema and Delays Its Resolution In Mice. J Physiol 2004, 560:857-865.

65. Rezaiguia S, Garat C, Delclaux C, Meignan M, Fleury J, Legrand P, et al.: Acute bacterial pneumonia in rats increases alveolar epithelial fluid clearance by a tumor necrosis factor-alphadependent mechanism. J Clin Invest 1997, 99:325-335.

66. Viget NB, Guery BP, Ader F, Neviere R, Alfandari S, Creuzy C, et al.: Keratinocyte growth factor protects against Pseudomonas aeruginosa- induced lung injury. Am J Physiol Lung Cell Mol Physiol 2000, 279:LI I99-LI 209.

67. Kunzelmann K, Beesley AH, King NJ, Karupiah G, Young JA, Cook DI: Influenza virus inhibits amiloride-sensitive $\mathbf{N a}+$ channels in respiratory epithelia. Proc Natl Acad Sci U S A 2000, 97:10282-10287.

68. Cloutier MM, Wong D, Ogra PL: Respiratory syncytial virus alters electrophysiologic properties in cotton rat airway epithelium. Pediatr Pulmonol 1989, 6: I64- I68.

69. Lambert LC, Trummell HQ, Singh A, Cassell GH, Bridges RJ: Mycoplasma pulmonis inhibits electrogenic ion transport across murine tracheal epithelial cell monolayers. Infect Immun 1998, 66:272-279.

70. Zhang M, Jion Kim K, IYer D, Lin Y, Belisle J, McEnery K, et al.: Effects of Mycobacterium tuberculosis on the bioelectric properties of the alveolar epithelium. Infect Immun 1997, 65:692-698.

7I. Stutts MJ, Schwab JH, Chen MG, Knowles MR, Boucher RC: Effects of Pseudomonas aeruginosa on bronchial epithelial ion transport. Am Rev Respir Dis 1986, I34: 17-21.

72. Towne JE, Krane CM, Bachurski CJ, Menon AG: Tumor necrosis factor-alpha inhibits aquaporin 5 expression in mouse lung epithelial cells. J Biol Chem 200 I, 276: I8657-I8664.

73. Galietta LJ, Folli C, Marchetti C, Romano L, Carpani D, Conese M, et al.: Modification of transepithelial ion transport in human cultured bronchial epithelial cells by interferon-gamma. Am J Physiol Lung Cell Mol Physiol 2000, 278:LI I86-LI I 94.

74. Frank J, Roux J, Kawakatsu H, Su G, Dagenais A, Berthiaume $Y$, et al.: TGF- $\beta$ I Decreases $\alpha$ ENaC Expression and alveolar Epithelial Vectorial sodium and Fluid Transport via an ERK I/2dependent Mechanism. J Biol Chem 2003, 278:43939-43950. 